\title{
In Vivo Expression and Regulation of Elk-1, a Target of the Extracellular-Regulated Kinase Signaling Pathway, in the Adult Rat Brain
}

\author{
Véronique Sgambato, ${ }^{1}$ Peter Vanhoutte, ${ }^{1}$ Christiane Pagès, ${ }^{1}$ Monique Rogard, ${ }^{1}$ Robert Hipskind, ${ }^{2}$ \\ Marie-Jo Besson, ${ }^{1}$ and Jocelyne Caboche ${ }^{1}$ \\ ${ }^{1}$ Laboratoire de Neurochimie-Anatomie, Institut des Neurosciences-Unité de Recherche Associée 1488, Université Pierre \\ et Marie Curie, 75005 Paris, France, and 2Institut de Génétique Moléculaire, Unité Mixte de Recherche 5535, Centre \\ National de la Recherche Scientifique, 34033 Montpellier, France
}

\begin{abstract}
The transcription factor Elk-1, a nuclear target of extracellularregulated kinases (ERKs), plays a pivotal role in immediate early gene induction by external stimuli. Notably, the degree of phosphorylation of Elk-1 is tightly correlated with the level of activation of transcription of c-fos by proliferative signals. No data yet indicate the role of Elk-1 in the adult brain in vivo. To address this question, we have analyzed in the present work (1) Elk-1 mRNA and protein expression in the adult rat brain, and (2) the regulation of Elk-1 (i.e., its phosphorylation state) in an in vivo model of immediate early gene (IEG) induction: an electrical stimulation of the cerebral cortex leading to c-fos and zif268 mRNA induction in the striatum. Using in situ hybridization, we show that Elk-1 mRNA is expressed in various brain structures of adult rat, and that this expression is exclusively neuronal. We demonstrate by immunocytochemistry using various specific
\end{abstract}

Elk-1 antisera that the protein is not only nuclear (as shown previously in transiently transfected cell lines) but is also present in soma, dendrites, and axon terminals. On electrical stimulation of the glutamatergic corticostriatal pathway, we show a strict spatiotemporal correspondence among ERK activation, Elk-1 phosphorylation, and IEG mRNA induction. Furthermore, both activated proteins, analyzed by immunocytochemistry, are found in cytosolic and nuclear comparments of neuronal cells in the activated area. Our data suggest that the ERK signaling pathway plays an important role in regulating genes controlled by serum response element sites via phosphorylation of Elk-1 in vivo.

Key words: SRE; Elk-1; transcription factor; mRNA expression; subcellular distribution; phosphorylation; ERK; electrical stimulation; striatum; immediate early gene induction
In the CNS excitatory neurotransmission can elevate calcium concentration in neuronal cells and can trigger activation of transcription of a class of genes known as immediate early genes (IEGs) (Sheng and Greenberg, 1990; Ginty et al., 1992; Ghosh and Greenberg, 1995). The characterization of calcium regulation of the prototypical IEG c-fos has provided a structural framework useful for understanding how this second messenger ion governs early nuclear events that affect neuronal plasticity. Within the promoter of c-fos, there are at least two critical response elements with activity that is regulated by calcium signaling (for review, see Ginty, 1997): the cAMP-Ca ${ }^{2+}$ responsive element (CRE) and the serum response element (SRE).

The SRE, located at position -310 in the c-fos promoter, was initially described as a protein-binding site required for the induction of c-fos expression by serum (Treisman, 1992). It serves as the site of assembly of multiprotein complexes that include a dimer of serum response factor (SRF) (Treisman, 1986; Norman et al., 1988; Schröter et al., 1990) together with ternary complex factor (TCF) (Shaw et al., 1989; for review, see Treisman, 1992, 1995). A major regulatory input received by the SRE can be

Received July 21, 1997; revised Oct. 10, 1997; accepted Oct. 21, 1997.

This work was supported by the University Pierre and Marie Curie, the Centre National de la Recherche Scientifique, Institut Lilly, and Biomed Program Grant PL 962215. We thank Drs. D. Stéhelin and D. Grévin for the gift of mouse Elk-1 cDNA, R. Zinck for providing Elk-1 antisera, and Dr. A. Thriller for confocal analysis.

Correspondence should be addressed to Jocelyne Caboche, Laboratoire de Neurochimie-Anatomie, Institut des Neurosciences-Unité de Recherche Associée 1488, Université Pierre et Marie Curie, 9 quai St-Bernard, 75005 Paris, France.

Copyright (C) 1997 Society for Neuroscience $0270-6474 / 97 / 180214-13 \$ 05.00 / 0$ attributed to TCF phosphorylation (Hill et al., 1993). The TCFs represent a subgroup of the ETS domain transcription factor family that comprises at least three members, Elk-1, SAP1, and SAP2/ERP/Net (Hipskind et al., 1991; Dalton and Treisman, 1992; Giovane et al., 1994; Lopez et al., 1994). Among TCFs, the most attention has been directed toward Elk-1, the first TCF to be identified (Hipskind et al., 1991). Elk-1 is rapidly phosphorylated on $\mathrm{Ser}^{383}$ and $\mathrm{Ser}^{389}$ in its C-terminal region in response to activation of the extracellular-regulated kinases (ERKs) of the mitogen-activated protein (MAP) kinase family. Phosphorylation at these sites increases its ability to form a ternary complex with SRE and SRF (Gille et al., 1992, 1995) and to potentiate definitively its ability to activate c-fos transcription strongly (Hill et al., 1993; Marais et al., 1993; Janknecht et al., 1994; Zinck et al., 1995; Hipskind et al., 1994a,b).

In the CNS, ERK proteins can be activated after glutamate receptor stimulation (Bading and Greenberg, 1991; Fiore et al., 1993b; Kurino et al., 1995). However, no clear link has been established among ERK activation, Elk-1 phosphorylation, and gene regulation on glutamate activation or in any in vivo model.

In this study we first analyzed the expression of Elk-1 mRNA and the corresponding protein in adult rat brain. Using in situ hybridization, we confirmed that Elk-1 mRNA is strongly expressed in adult brain (Price et al., 1995) and observed that it is restricted to neuronal cells. Immunocytochemistry revealed that Elk-1 protein is nuclear as expected (Janknecht et al., 1994; Pingoud et al., 1994) and surprisingly associated with the cytosol. In a second step we used an in vivo stimulation of cortical cells 
inducing c-fos and zif268 mRNA in the projection field of the stimulated cortical area: the lateral striatum. The hyperphosphorylation of both ERK and Elk-1 was found in a strict spatiotemporal correspondence with c-fos and zif 268 mRNA induction in the activated striatal area. The presence of phosphorylated signaling components in both nuclear and cytoplasmic compartments suggests that the activation of both ERK and Elk-1 can occur locally, near the calcium influx source, and thus provides novel insights on the mechanisms by which calcium influences gene regulation.

\section{MATERIALS AND METHODS}

Tissue preparation for in situ hybridization and immunohistochemistry. Adult male Sprague Dawley rats (250-300 gm) were housed under standard conditions. After intraperitoneal injection of sodium pentobarbital (0.2 $\mathrm{mg} / \mathrm{gm}$ total body weight), rat brains were fixed by intracardiac perf usion of $4 \%$ paraformaldehyde (PFA) in $0.1 \mathrm{M} \mathrm{Na}_{2} \mathrm{HPO}_{4} / \mathrm{NaH}_{2} \mathrm{PO}_{4}$ buffer, $\mathrm{pH} 7.5$ (phosphate buffer), delivered with a peristaltic pump at $50 \mathrm{ml} / \mathrm{min}$ during $10 \mathrm{~min}$. Brains were removed and post-fixed in the same fixing solution for $2 \mathrm{hr}$, washed overnight in $0.1 \mathrm{M}$ phosphate buffer containing $15 \%$ sucrose, and then frozen in isopentane $\left(1 \mathrm{~min}\right.$ at $\left.-25^{\circ} \mathrm{C}\right)$. Sections $(20 \mu \mathrm{m})$ were cut on a microtome and then kept in a solution containing $30 \%$ ethylene glycol, $30 \%$ glycerol, $0.1 \mathrm{M}$ phosphate buffer, and $0.1 \%$ diethyl pyrocarbonate (DEPC; Sigma, St. Louis, MO) at $-20^{\circ} \mathrm{C}$ until processed for in situ hybridization or immunohistochemistry.

Probe synthesis. The antisense (complementary to cellular mRNA) and control sense (identical to cellular mRNA) probes used in this study were ${ }^{33} \mathrm{P}$-radiolabeled riboprobes. Elk-1 RNA probes were produced by in vitro transcription of a $3^{\prime}$ region of a mouse $475 \mathrm{bp}$ cDNA subcloned into Bluescript (Stratagene, La Jolla, CA). For the antisense riboprobe, the recombinant plasmid containing the Elk-1 insert was linearized with $X h o I$ and transcribed with T3 RNA polymerase; for the sense probe, the plasmid was linearized with BamHI and transcribed with T7 RNA polymerase. For c-fos antisense riboprobe a human c-Fos cDNA subclone (pBFH480) corresponding to exon 4 was linearized after HindIII digestion and transcribed with T7 RNA polymerase. The sense probe was obtained after linearization with EcoRI and transcribed with T3 RNA polymerase. For zif268 antisense riboprobe of a murine zif268 cDNA subclone (Bluescript) corresponding to $1.6 \mathrm{~kb}$ was linearized after HindIII digestion and transcribed with T7 RNA polymerase; the sense probe was obtained after linearization with EcoRI digestion and transcribed with T3 RNA polymerase. Transcription reactions contained $1 \mu \mathrm{M}$ $\left[\alpha^{3}{ }^{33}\right.$ P]UTP $(3000 \mathrm{Ci} / \mathrm{mmol}$, Isotopchim), $250 \mu \mathrm{M}$ ATP, CTP, and GTP, and unlabeled UTP $(10.5 \mu \mathrm{M})$ and were incubated at $39^{\circ} \mathrm{C}$ for $2 \mathrm{hr}$. After DNase I digestion, the labeled RNA was purified by phenol/chloroform/ isoamyl alcohol (25:24:1) extraction and ethanol precipitation. Gel electrophoresis showed the transcripts to be predominantly full-length.

In situ hybridization. Free-floating sections were mounted on SuperFrost Plus slides (Menzel-Gläser) in RNase-free conditions. Once dried, mounted sections were rinsed in PBS and treated for 10 min with $0.1 \mathrm{M}$ glycine in $0.1 \mathrm{M}$ Tris- $\mathrm{HCl}, \mathrm{pH}$ 7.4. Sections were rinsed for $5 \mathrm{~min}$ at $37^{\circ} \mathrm{C}$ in $0.1 \mathrm{M}$ Tris- $\mathrm{HCl}, \mathrm{pH} 8$, and $50 \mathrm{~mm}$ EDTA and treated for $15 \mathrm{~min}$ at $37^{\circ} \mathrm{C}$ with $1 \mathrm{mg} / \mathrm{ml}$ proteinase $\mathrm{K}$ in the same buffer. Before hybridization sections were subjected to the following treatments: post-fixation for 15 min in $4 \%$ PFA and $5 \mathrm{~mm} \mathrm{MgCl}_{2}$ in PBS at room temperature, acetylation for $20 \mathrm{~min}$ in acetic anhydride/triethanolamine, $\mathrm{pH} 8$, at room temperature and stepwise dehydration in alcohol. The following hybridization solution was applied on sections, which were then covered with GelBond film (FMC Bioproducts, Rockland, ME). The hybridization mixture contained $200 \mathrm{ng} / \mathrm{ml}(4 \mathrm{ng} / \mathrm{section})$ of ${ }^{33} \mathrm{P}$-RNA probe in $20 \mathrm{~mm}$ Tris-HCl, pH 8, $300 \mathrm{~mm} \mathrm{NaCl}, 5$ mm EDTA, 10\% dextran sulfate, $1 \times$ Denhardt's solution $(0.02 \%$ Ficoll, $0.02 \%$ polyvinyl pyrolidone, and 10 $\mathrm{mg} / \mathrm{ml} \mathrm{BSA}$ ), $0.5 \mathrm{mg} / \mathrm{ml}$ Escherichia coli tRNA, $0.1 \mathrm{M}$ dithiothreitol (DTT), and $50 \%$ formamide. Hybridization was performed at $60^{\circ} \mathrm{C}$ in humid chambers for $16 \mathrm{hr}$. After removing the GelBond coverslips in $4 \times$ SSC and $10 \mathrm{~mm}$ DTT, the slides were washed in the same solution for 1 $\mathrm{hr}$ at room temperature and then in $50 \%$ formamide, $10 \mathrm{~mm}$ Tris- $\mathrm{HCl}$, $\mathrm{pH} 8,75 \mathrm{~mm} \mathrm{NaCl}$, and $2.5 \mathrm{~mm}$ EDTA. Sections were treated with RNase A $(20 \mu \mathrm{g} / \mathrm{ml}$, Sigma $)$ in $400 \mathrm{~mm} \mathrm{NaCl}, 10 \mathrm{~mm}$ Tris- $\mathrm{HCl}, \mathrm{pH} 7.5$, and 50 mM EDTA for $1 \mathrm{hr}$ at $37^{\circ} \mathrm{C}$, and then rinsed for $15 \mathrm{~min}$ at $60^{\circ} \mathrm{C}$ in $2 \times \mathrm{SSC}$ followed by $0.1 \times$ SSC. After dehydration, sections were air-dried and exposed with Biomax MR films (Eastman Kodak, Rochester, NY) for 3 d. The slides were then coated with NTB3 emulsion (Kodak) and exposed for 3 weeks. After development slides were counterstained with cresyl violet and mounted with Eukitt (Calibrated Instruments).

Immunohistochemistry. The immunohistochemical procedure was adapted from protocols previously described. On day 1, free-floating sections were rinsed in Tris-buffered saline (TBS; $0.25 \mathrm{M}$ Tris and $0.5 \mathrm{M}$ $\mathrm{NaCl}, \mathrm{pH} 7.5$ ), incubated for $5 \mathrm{~min}$ in TBS containing $3 \% \mathrm{H}_{2} \mathrm{O}_{2}$ and $10 \%$ methanol, and then rinsed three times 10 min each in TBS. After a 15 min incubation in $0.2 \%$ Triton X-100 in TBS, sections were rinsed three times in TBS, preincubated for $30 \mathrm{~min}$ in TBS containing $30 \%$ normal goat serum, and washed three times for $10 \mathrm{~min}$ in TBS. Sections were then incubated for $72 \mathrm{hr}$ at $4^{\circ} \mathrm{C}$ with the following primary antibodies. Rabbit polyclonal antisera raised against synthetic peptides (Santa Cruz Biotechnology, Santa Cruz, CA; and Upstate Biotechnology, Lake Placid, NY) encompassing the regions listed (as amino acids) in each protein, (1) 407-428 of Elk-1, (2) 123-137 of CRE-binding protein (CREB), and (3) 686-709 of signal transducers and activators of transcription (STAT3), were used at a dilution of 1:100 in TBS containing 1\% goat serum and $1 \%$ rat serum. Rabbit polyclonal antibodies raised against recombinant proteins containing $\mathrm{N}$ - or $\mathrm{C}$-terminal regions of human Elk-1 were used at a dilution of 1:500 in the same buffer. On day 2 , after three rinses in TBS, sections were incubated $24 \mathrm{hr}$ at $4^{\circ} \mathrm{C}$ with the secondary, biotinylated antibody (rabbit anti-IgG) using a dilution twice that of the first antibody in TBS containing $1 \%$ normal rat serum and $1 \%$ normal goat serum. On day 3 , after washing the sections three times in TBS, they were incubated for $90 \mathrm{~min}$ in avidin-biotin-peroxidase complex solution (Vector Laboratories, Burlingame, CA; final dilution, 1:50). Sections were washed two times in TBS and two times in Tris buffer (TB; $0.25 \mathrm{M}$ Tris, $\mathrm{pH} 7,5) 10 \mathrm{~min}$ each, placed in a solution of TB containing $0.1 \%$ 3-3' diaminobenzidine $(50 \mathrm{mg} / 100 \mathrm{ml})$, and developed by $\mathrm{H}_{2} \mathrm{O}_{2}$ addition $(0.02 \%)$ for $60 \mathrm{~min}$. After processing, tissue sections were mounted onto gelatin-coated slides and dehydrated through alcohol to xylene for light microscopic examination. For confocal microscopic analysis, the same procedure was applied on day 1 . On day 2, sections were incubated with the Cy3-labeled goat anti-rabbit IgG (Amersham, Les Ulis, France) at a dilution 1:200 in TBS containing gelatin (1:40). After five washes in TBS and one wash in distilled water, sections were mounted onto gelatin-coated slices with Vectashield (Vector) mounting medium.

Confocal analysis. Confocal data were obtained using a Sarastro 2000 confocal microscope (Molecular Dynamics, Sunnyvale, CA) at $63 \times(1.4$ numerical aperture) magnification. Excitation was achieved with the 514 $\mathrm{nm}$ ray of an argon ion laser, and the emitted light was selected by using appropriate filters. The contrast was enhanced, and the background was reduced by applying a $3 \times 3 \times 3$ Gaussian filter on the series of digitized optical sections. Maximum intensity projections were computed with the Image Space software (Molecular Dynamics).

Phospho-ERK and phospho-Elk-1 immunocytochemistry. Sections were processed as described above with the following modifications. NaF $(0.1$ $\mathrm{mm}$ ) was included in all buffers and incubation solutions, and all steps that included normal goat serum and normal rat serum were omitted. These were incubated with commercial available antisera produced by immunizing rabbits with synthetic dual-specific anti-active MAP kinase (MAPK; Promega, Madison, WI) corresponding to $\mathrm{Thr}^{183}$ and $\mathrm{Tyr}^{185}$ in p42 MAPK (diluted 1:100) and phospho-Ser ${ }^{383}$ peptide corresponding to residues 379-392 of human Elk-1 (New England Biolabs, Beverly, MA) (diluted 1:80).

Double labeling by in situ hybridization and immunocytochemistry. Freefloating sections were processed for phospho (P-Elk) Elk-1 immunocytochemistry as described above, except that all buffers used were autoclaved and diluted with DEPC-treated water. Sections were mounted onto SuperFrost Plus slides and air-dried for at least $60 \mathrm{~min}$, followed by zif268 in situ hybridization as indicated above.

Tissue preparation for Western blot analysis. Tissue samples were rapidly extracted from the brain and lysed in solubilization buffer $(10 \mathrm{~mm}$ Tris-Cl, $50 \mathrm{~mm} \mathrm{NaCl}, 1 \%$ Triton $\mathrm{X}-100,30 \mathrm{~mm}$ sodium pyrophosphate, $50 \mathrm{~mm} \mathrm{NaF}, 5 \mu \mathrm{M} \mathrm{ZnCl}, 100 \mu \mathrm{M} \mathrm{Na} \mathrm{VO}_{4}, 1 \mathrm{~mm}$ DTT, $5 \mathrm{~nm}$ okadaic acid, $2.5 \mu \mathrm{g}$ of aprotinin, $2.5 \mu \mathrm{g}$ of pepstatin, $0.5 \mu \mathrm{M}$ PMSF, $0.5 \mathrm{~mm}$ benzamidine, and $2.5 \mu \mathrm{g}$ of leupeptin). Insoluble material was removed by centrifugation $\left(13,000 \mathrm{rpm}\right.$ for $20 \mathrm{~min}$ at $\left.4^{\circ} \mathrm{C}\right)$. Cell lysates $(10$ $\mu \mathrm{g} /$ lane) were separated by $10 \%$ SDS-PAGE before electrophoretic transfer onto a polyvinylidene difluoride membrane (ICN Biochemicals). The blots were blocked ( $1 \mathrm{hr}$ room temperature) with 5\% nonfat dry milk and incubated (overnight at $4^{\circ} \mathrm{C}$ ) with a rabbit polyclonal antiserum raised against peptide 407-428 of Elk-1 (anti-Elk-1, 1:200; Santa Cruz). The blots were subsequently incubated for $2 \mathrm{hr}$ at room temperature with 
goat anti-rabbit horseradish peroxidase-conjugated antibodies before exposure to the ECL substrate. For the detection of the active forms of the proteins, the same procedure was applied except for the following modifications. For P-Elk-1 detection, $30 \mu \mathrm{g}$ of protein/lane was loaded on the SDS-PAGE. The saturation step was performed in BSA (fraction V, Sigma), 5\% (for P-ERK) and 8\% (for P-Elk-1). The antibody specifically directed against the phosphorylated proteins was first applied (P-ERK, 1:2500; P-Elk-1, 1:100), and the revelation was processed as described above. Then the blots were stripped (glycine- $\mathrm{HCl}, \mathrm{pH} 2.8$, two times for $20 \mathrm{~min}$ each at $55^{\circ} \mathrm{C}$, followed by saturation in $5 \%$ nonfat dry milk) and incubated with the antibodies corresponding to the nonactivated proteins as described above. The efficacy of the stripping step was assessed by omitting the first antibody and verifying the lack of signals on the blot.

Corticostriatal stimulations. After anesthesia with pentobarbital (Sanofi; $6 \mathrm{mg} / \mathrm{kg}$, i.p.), cortical stimulations were applied in animals placed in a conventional stereotaxic apparatus. Care was taken to minimize uncontrolled sources of stimulation; the skin around the points of stereotaxic contention and areas of incision were numbed with xylocaine. Body temperature was monitored throughout the experiment and kept at $37-38^{\circ} \mathrm{C}$ with a homeothermic blanket. A small craniotomy was made over the orofacial area of the motor cortex according to previously described stereotaxic coordinates (Paxinos and Watson, 1986). Orofacial cortical stimulations were applied through pairs of wires (Ni-chrome, 0.2 $\mathrm{mm}$ diameter) $1.5 \mathrm{~mm}$ apart and inserted at a depth of $1.5 \mathrm{~mm}$ from the cortical surface. Electrical stimuli consisted of trains of pulses of $200 \mu \mathrm{A}$ intensity and $50 \mathrm{msec}$ duration delivered at frequencies of $250 \mathrm{~Hz}$, repeated at $4 \mathrm{~Hz}$ for $15 \mathrm{~min}$. The localization of the jaw area was precisely identified by observing the motor effects evoked by these electrical pulses. The polarity of electrodes was reversed every $30 \mathrm{sec}$ to avoid lesion of cortical tissue. After the end of stimulation, brains were processed for either neuroanatomical (in vivo perfusion with $4 \%$ PFA) or biochemical (rapid extraction of lateral or medial part of the striatum) studies. Sham-operated rats were treated identically, except that no electrical stimulation was delivered.

Kainic acid lesion of striatal cells. Kainic acid $(0.8 \mu \mathrm{l}, 2 \mu \mathrm{g} / \mu \mathrm{l}$; Sigma) was delivered unilaterally in the lateral part of the striatum by means of pressure injections through a Hamilton syringe fitted with a glass micropipettes (internal tip diameter, $50 \mu \mathrm{m}$ ). The injection was made over $10 \mathrm{~min}$, and the needle was left in place for $15 \mathrm{~min}$ before withdrawal After a postoperative period of $10 \mathrm{~d}$, animals were deeply anesthetized and perfused transcardially as described above.

\section{RESULTS}

\section{Elk-1 mRNAs are differentially expressed in adult rat brain structures}

To identify the regions of Elk-1 expression in the brain, sections were hybridized with Elk-1 antisense and sense ${ }^{33}$ P-cRNA probes. To label Elk-1 mRNAs specifically and to avoid detection of mRNAs encoding the other ets-related proteins, we chose a probe corresponding to the $3^{\prime}$ region of the mouse Elk-1-cDNA, which presents very few sequence homologies with other etsrelated cDNAs (Wasylyk et al., 1993). The sense Elk-1 ${ }^{33}$ P-cRNA probe showed no detectable signal on autoradiograms (Fig. 1A, inset). The antisense Elk-1 ${ }^{33} \mathrm{P}$-cRNA probe revealed a wide and heterogeneous expression of Elk-1 mRNA in the whole rostrocaudal extension of the rat brain (Fig. 1A-I). Quantification by densitometry showed a very high level of Elk-1 mRNA expression in the granular layer of olfactory bulbs, the pyriform cortex, the dentate gyrus of the hippocampus, and the granular layer of the cerebellum. The labeling was relatively strong in the nucleus accumbens, the caudate-putamen, various nuclei of the thalamus, the CA layers in the hippocampus, the substantia nigra pars compacta, the pedonculopontine nucleus, and throughout the whole cerebral cortex. A low level of expression was observed in the lateral and medial septal nuclei, the substantia nigra pars reticulata $(\mathrm{SNr})$, and the external segment of the globus pallidus (GPe). No significant hybridization signals were obtained in structures corresponding to white matter. To visualize hybridiza- tion of Elk-1 mRNA at the cellular level, high-resolution emulsion autoradiograms of sections were processed after cresyl violet counterstaining to allow the identification of neuronal and glial cells. The sense probe gave very weak, uniformly distributed hybridization signals in all brain sections (data not shown). In all brain structures examined, cells of neuronal subtypes showed strong Elk-1 mRNA-specific hybridization signals (Fig. $1 J$ ). In contrast, glial cells, characterized by a strong nuclear coloration with cresyl violet coloration, showed very low labeling (the astrocytes in the cerebral cortex; Fig. $1 J$ ) or none, as exemplified by the very weak signals in the corpus callosum (Fig. $1 K$ ).

\section{Immunocytochemistry reveals nuclear and cytoplasmic localization of Elk-1 protein}

Expression of Elk-1 protein was assessed in three different structures: the striatum, the CA1 layer of the hippocampus, and the Purkinje cell layer of the cerebellum (Fig. 2), using an antiserum specific for the Elk-1 C terminus (COOH antibody). Its specificity was confirmed using Western blots, which yielded a band of 62 $\mathrm{kDa}$ (apparent molecular weight) for each cerebral structure (Fig. $2 A)$. In the striatum, the immunocytochemical labeling of Elk-1 was very dense in the neuropil. Neuronal cells were labeled in both nuclear and somatic compartments (Fig. 2B, arrow), along with some dendritic processes (Fig. 2B, arrowheads). A subpopulation of striatal cells also showed an exclusively somatic and dendritic immunoreactivity (see Fig. 4). In the hippocampus, the dendritic arborization of the pyramidal cells of the CA1 layer was also very densely labeled by this antiserum (Fig. 2B, arrowheads) together with the nucleus and the cytoplasm. In the cerebellum, Elk-1 immunoreactivity was concentrated within the cell bodies and dendrites of Purkinje cells (Fig. 2, arrowhead). In addition, the molecular layer showed a diffuse reactivity of moderate intensity throughout the molecular layer. No labeling of glial cells was observed (data not shown). In all cases, the immunocytochemical labeling of Elk-1 was blocked by preadsorbing the serum with the immunizing peptide (data not shown).

Elk-1 localizes in the nucleus in transiently transfected HeLa cells and is associated predominantly with the nuclear fraction in these cells (Pingoud et al., 1994). The antisera used for this localization, those directed against the entire $\mathrm{C}$-terminal region (C-terminal antibody) or the whole N-terminal Ets-domain (Ets antibody) specifically label a $62 \mathrm{kDa}$ endogenous protein that is indistinguishable from Elk-1 by multiple criteria (Pingoud et al., 1994). We compared the pattern of Elk-1 expression obtained with the various Elk-1 antibodies $(\mathrm{COOH}, \mathrm{C}$-terminal, and Ets; Fig. 3, top panel) in neuronal cells. In the pyramidal cell layers of the cerebral cortex (Fig. $3 A$ ), all three antisera stain Elk-1 in the nucleus (thin arrows), cytosol (arrows), and dendrites (arrowheads). Thus Elk-1 is found in several different cellular compartments in neuronal cells. To test our conditions of immunocytochemical detection, we performed a similar characterization of two other transcription factors, the proteins CREB (Fig. 3B) and STAT3 (Fig. 3C). The subcellular localization of both factors is well established, and both play a key role in c-fos activation. Immunolabeling of CREB was exclusively nuclear, whereas STAT3 was present within the cytoplasm in neuronal cell bodies, a result consistent with its cytoplasmic localization before activation (Darnell et al., 1994).

In some cases, neurons showed an exclusively somatic and dendritic Elk-1 immunoreactivity. This was confirmed using confocal microscopic imagery (Fig. 4). In confocal sections of two striatal neurons (Fig. 4A1,B1), the fluorescent signal (predomi- 

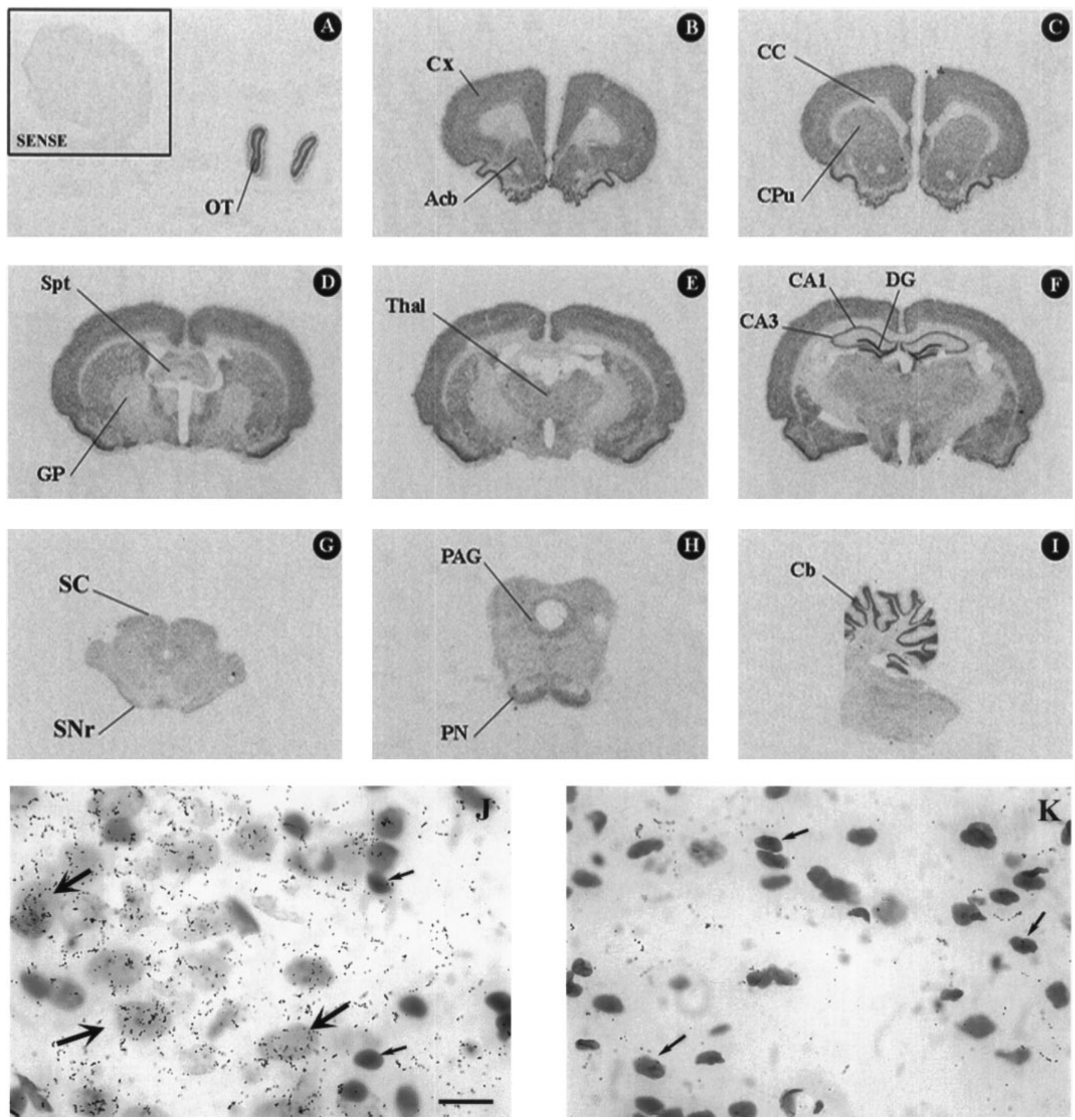

Figure 1. In situ detection of Elk-1 mRNA in rat brain. Rat cerebral sections were hybridized with ${ }^{33} \mathrm{P}-\mathrm{cRNA}$-Elk-1 sense $(A$, inset $)$ and antisense $(A-I)$ probes. Coronal sections ( $20 \mu \mathrm{m}$ thick) were taken in the whole rostrocaudal extension of the rat brain. The cerebellum was taken according to a sagittal plane. $O T$, Olfactory tubercles; $C x$, cerebral cortex; $A c b$, accumbens nucleus; $C C$, corpus callosum; $C P u$, caudate-putamen; $S p t$, septum; $G P$, globus pallidus; Thal, thalamus; $C A$, Amon corn layer of the hippocampus; $D G$, dentate gyrus of the hippocampus; $S C$, superior colliculi; $S N r$, substantia nigra pars reticulata; $P A G$, periaqueducal gray layer; $P N$, pedonculopontine nuclei; $C b$, cerebellum. $J$, High magnification $(500 \times)$ of Elk-1 mRNA hybridization in the CA1 layer of hippocampus. The cresyl violet counterstaining allows the characterization of glial (small arrows) and neuronal (large arrows) cells. Note that hybridization signals are always observed on neuronal cells. Scale bar, $17 \mu \mathrm{m}$. $K$, Elk-1 hybridization in the corpus callosum (glial cells, small arrows).

nated) in the somatic compartment (arrows), whereas the nuclei were devoid of staining. Dendritic immunoreactivity (Fig. $4 A 2, B 2$, arrowheads) was clearly visible in maximum intensity projections.
Other regions, such as the GPe and the $\mathrm{SNr}$, also showed very dense labeling for Elk-1 protein (Fig. $5 A, C$ ) despite low levels of Elk-1 mRNA expression (Fig. $1 D, G$ ). In fact, this labeling represented a very small subset of cells within a dense neuropil (Fig. 

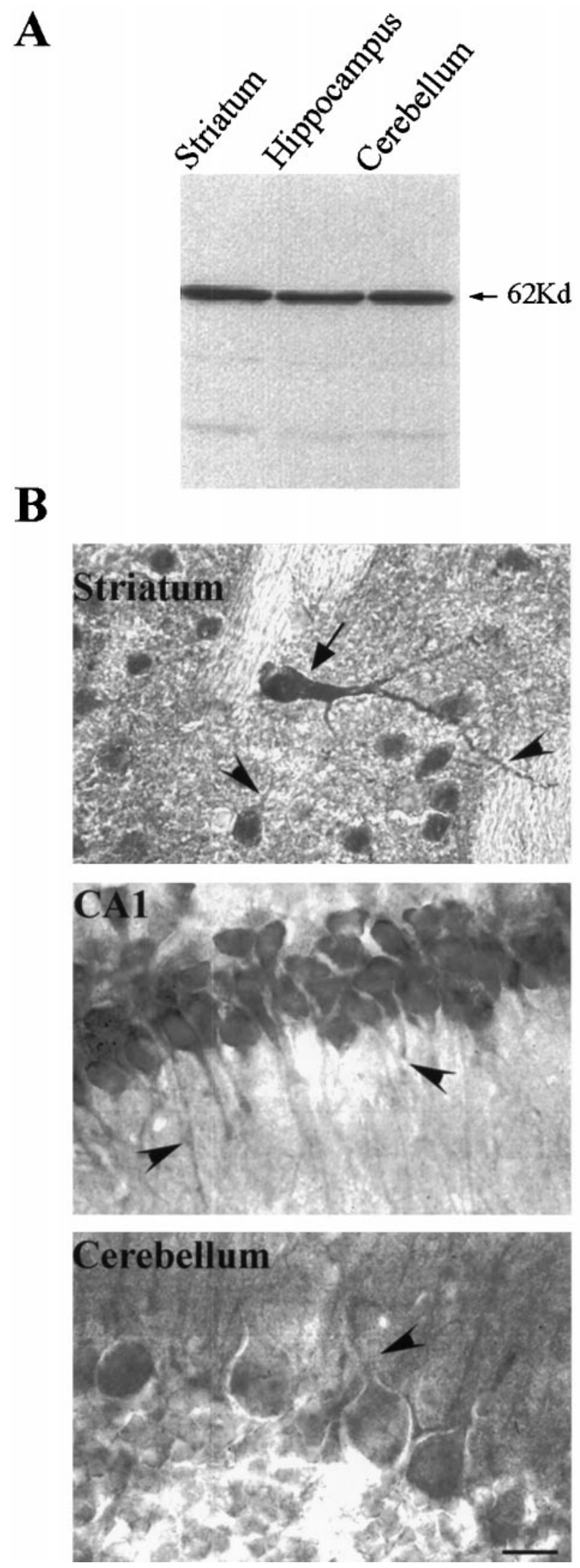

Figure 2. Expression of Elk-1 protein in various brain structures. $A$, Western blot analysis of Elk-1 expression in the striatum, the hippocampus, and the cerebellum. The $\mathrm{COOH}$ antibody yields a band with an apparent molecular weight of $62 \mathrm{kDa}$ (protein molecular weight standards). $B$, Immunocytochemical detection of Elk-1 using the $\mathrm{COOH}$
$5 A, C)$. To determine whether this immunoreactive neuropil represented axon terminals of striatal neurons, the major afferent structure of both GPe and SNr, we performed a unilateral kainic acid lesion of striatal neurons. This lesion led to a complete disappearance of striatal neurons ipsilaterally to the injection but not contralaterally. In the GPe and the SNr ipsilateral to the lesion, a marked loss of Elk-1 immunoreactivity was observed in the neuropil in the projection field of lesioned striatal neurons (Fig. 5B,D). By comparison, Elk-1 immunostaining remained intense in the neuropil in the GPe and in the $\mathrm{SNr}$ contralateral to the striatal lesion (Fig. $5 A, C$ ). These results indicate that Elk-1 is present not only in striatal cell bodies but also in striatopallidal and striatonigral afferent terminals.

\section{In vivo hyperphosphorylation of Elk-1 on corticostriatal stimulation}

The striatum receives a massive glutamatergic excitatory input originating from the whole cerebral cortex. In anesthetized rats, the sustained unilateral electrical stimulation of the cortex leads to Fos protein induction in the striatum, and this induction is topographically related to the stimulated cortical area (Sgambato et al., 1997). In particular, the stimulation of the sensorimotor cortex, which projects to the lateral part of the striatum, leads to Fos induction specifically in this region (Sgambato et al., 1997). This induction could already be observed $1 \mathrm{hr}$ after the end of stimulation, indicating a robust and rapid activation of c-fos. Because Elk-1 plays a key role in SRE-dependent activation of IEGs, we wished to evaluate whether it is targeted by the signals activated in this in vivo model of sensorimotor cortex stimulation. Activation of the ERK signaling pathway and phosphorylation of Elk-1 just precedes the appearance of mRNAs for IEGs such as c-fos and zif268, an IEG which contains four SRE sites in its promoter (Zinck et al., 1993; Hipskind et al., 1994a,b). We thus optimized experimental conditions to allow us to visualize IEG mRNAs and phosphorylation of ERK and Elk-1 concomitantly. These turned out to involve immediately sacrificing rats after a stimulation period of $15 \mathrm{~min}$.

\section{Model of IEG mRNA induction}

In sham-operated (implanted but not stimulated) rats (Fig. 6, left panels), in situ hybridization shows that c-fos and zif268 mRNAs are induced in the cortex ipsilateral to the electrode implantation. In the striatum, c-fos is not detectable, whereas zif 268 shows a moderate basal expression. In stimulated rats (Fig. 6, right panels), both RNAs are slightly induced in the cortex ipsilateral to the stimulation site. However, they show a strong and restricted induction bilaterally in the lateral part of the striatum, corresponding to the projection area of the stimulated cortical region, especially in comparison with the nonactivated striatal medial area.

\section{Hyperphosphorylation of ERK and Elk-1 spatiotemporally correlates with IEG mRNAs induction}

We have shown that Elk-1 is a nuclear and cytoplasmic transcription factor in the adult rat brain. We wondered whether Elk-1 might be activated in these various neuronal subcellular compart-

antibody. Shown are the striatum, the CA1 layer of hippocampus, and the Purkinje cell layer of the cerebellum. Elk-1 COOH antibody was used on rat brain sections processed in parallel. Note that in all three structures, the protein is present in the nucleus and the cytosol, as well as dendritic processes (arrowhead). Arrow, Heavy immunoreactivity for Elk-1 in a subpopulation of striatal cells. Scale bar, $17 \mu \mathrm{m}$. 


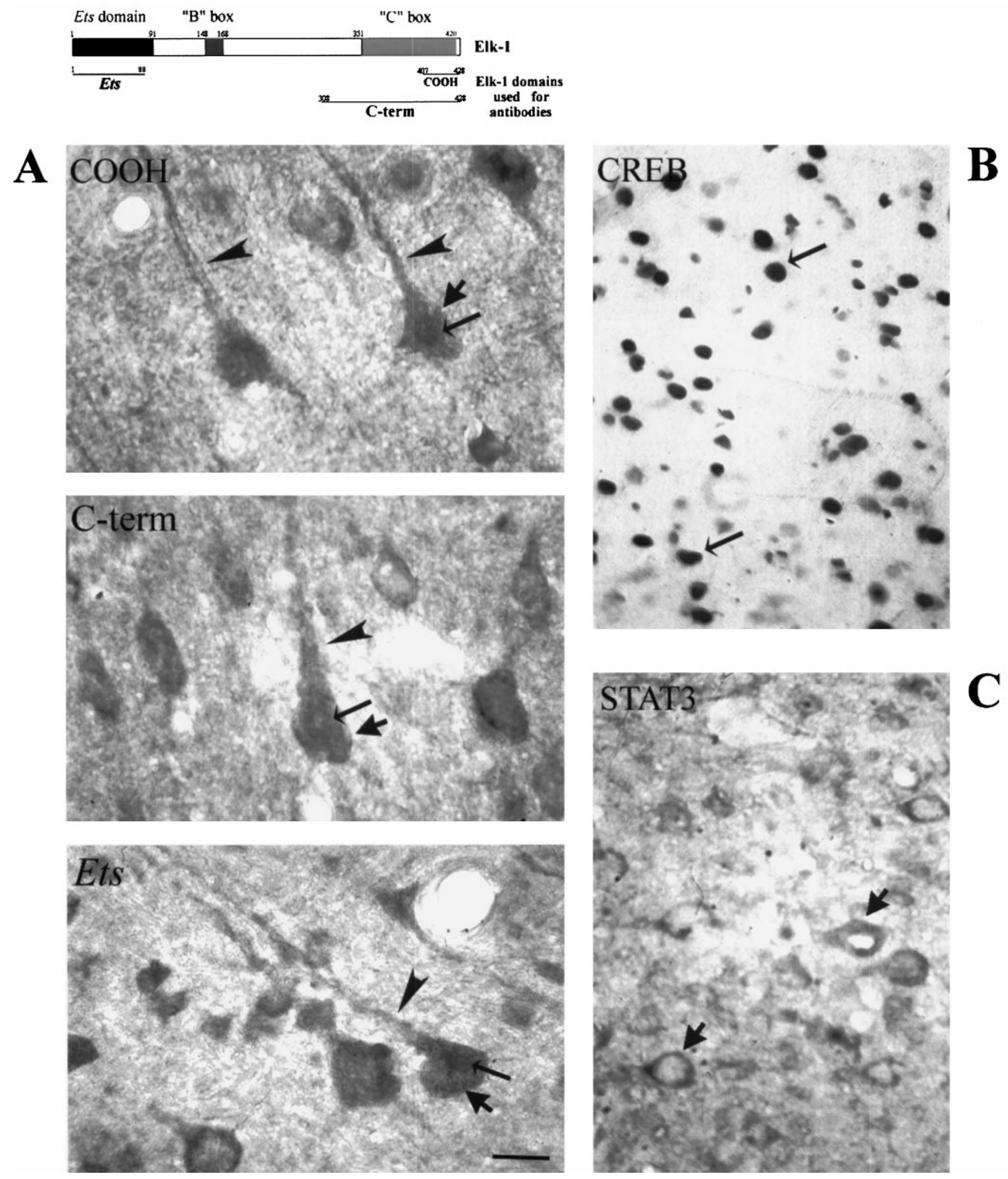

Figure 3. Subcellular localization of Elk-1, CREB, and STAT3 proteins in the pyramidal cell layer of the cerebral cortex. $A$, Serial sections were processed for immunocytochemistry with three different Elk-1 antibodies (described in the diagram at the top): anti-COOH, anti-C-terminal $(C$-term), and anti-Ets. Note that all three antibodies show the protein in the nucleus (thin-headed, long arrows), cytosol (short arrows), and also in dendritic processes (arrowheads) of neuronal cells. $B$, CREB and $C$, STAT3 immunocytochemistry in adjacent sections of cerebral cortex. Note the nuclear localization of CREB (B, thin-headed, long arrows) and the cytoplasmic localization of STAT3 (C, short arrows). Magnification, $500 \times$. Scale bar, $17 \mu \mathrm{m}$. 

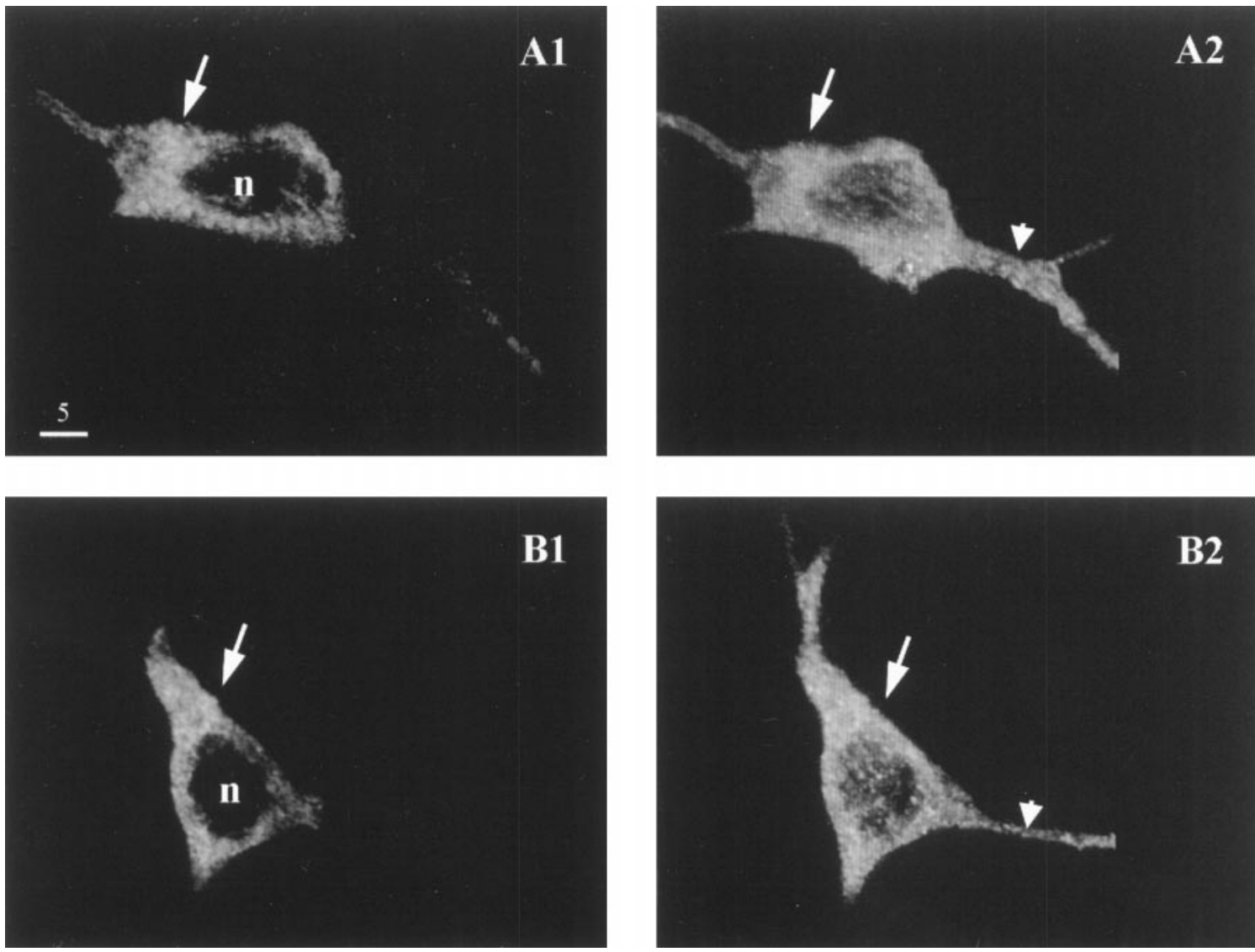

Figure 4. Visualization of Elk-1 immunoreactivity with confocal microscopy. Two examples of Elk-1-immunoreactive striatal neurons with COOH antibody. In these two cells, the fluorescent signal predominates in the somatic (arrows) and dendritic (arrowheads) cytoplasm, and the nuclei ( $n$ ) are not stained. $A 1, B 1$, Confocal sections; $A 2, B 2$, maximum intensity projection (25-28 sections, respectively). Scale bar, $5 \mu \mathrm{m}$.

ments after glutamatergic stimulation that leads to IEG mRNAs induction.

To address this question, we used our in vivo model of IEG mRNA induction after corticostriatal stimulation. We concentrated our analysis on the striatum, because this region showed a specific induction of IEG mRNAs by electrical stimulation. The activation of Elk-1 protein was examined by using an antibody that specifically and exclusively recognizes the phosphorylated (and therefore active) form of Elk-1 (see Materials and Methods). Because Elk-1 represents a major substrate of the ERK pathway, we also tested for ERK activation by using an antibody directed against the phosphorylated, active form of ERK (see Materials and Methods).

P-ERK (Fig. 7A-D) was analyzed on sections adjacent to those used for IEG mRNA detection (see Fig. 6). At low magnification, a marked increase in P-ERK immunolabeling was obvious in the lateral striatum (the activated area) in comparison to the medial striatum (the nonactivated area) (Fig. 7A), and this activation corresponded spatially with IEG mRNA induction. Highermagnification images showed numerous neurons with a strong P-ERK immunoreactivity in the lateral striatum, with labeling in the nucleus (Fig. 7C, arrow) as well as the cytoplasm, dendrites (Fig. 7C, arrowheads), and the neuropil (Fig. 7, compare C,B). Statistical analysis of P-ERK immunoreactivity indicated a dramatic increase of P-ERK immunoreactivity in the lateral striatum relative to the medial striatum $(+800 \% ; p<0.05)($ Fig. $7 D)$.

Elk-1 phosphorylation (P-Elk-1) was examined, as above, on adjacent sections (Fig. $7 E-H)$. As with P-ERK, P-Elk-1 immu- noreactivity was increased in the lateral part of the striatum, again in correspondence with the activated area (Fig. 7E). At higher magnification, a weak constitutive nuclear labeling appeared in medial striatal neurons (Fig. $7 F$ ). However, a marked increase in P-Elk-1 immunoreactivity appeared in the nucleus of lateral striatal cells (Fig. 7G, arrows). In this activated region, P-Elk-1 was also clearly detectable in cytoplasmic and dendritic compartments of some neurons (Fig. 7G, arrowheads). Statistical analysis showed a moderate but significant increase of P-Elk-1 immunoreactivity in the lateral striatum in comparison with the medial striatum $(+70 \%$; $p<0.05)$ (Fig. $7 H)$. Thus Elk-1 is activated on glutamatergic stimulation, in strong correlation both spatially and temporally with the activation of ERK and with c-fos and zif268 mRNA induction.

\section{Biochemical characterization of P-ERK and P-Elk-1 increase in the lateral striatum}

To confirm the P-ERK and P-Elk-1 immunocytochemical labeling biochemically, Western blots were performed on extracts prepared from the striata of stimulated rats. The P-ERK antiserum yielded two bands of 42 and $44 \mathrm{kDa}$, the expected sizes for ERKs 1 and 2. This immunoreactivity was clearly increased in the lateral striatal extracts relative to those from the medial striatum (Fig. 8, left panels). This reflects increased ERK activation, because comparable levels of ERKs 1 and 2 were present in both extracts (Fig. 8, left panels).

Western blots to detect endogenous P-Elk-1 have proven difficult to perform in cell lines expressing high levels of Elk-1 (R. A. 


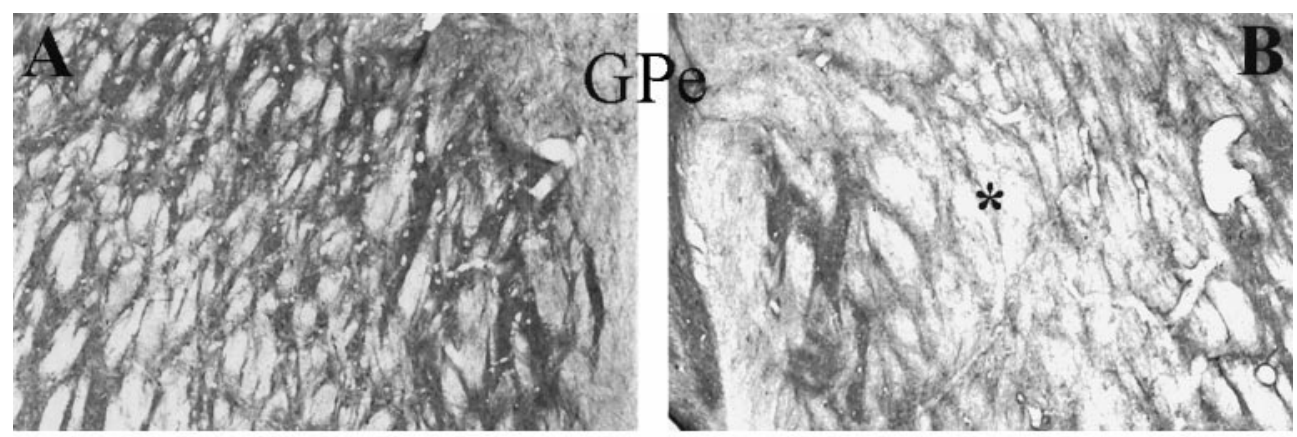

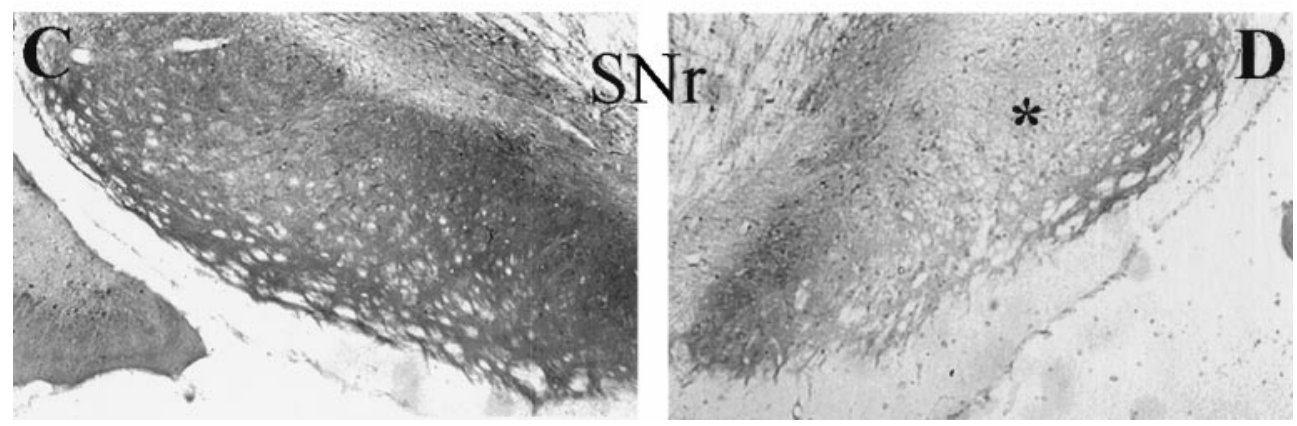

Figure 5. Elk-1 protein detection in striatopallidal and striatonigral axon terminals. After unilateral kainic acid lesion of striatal cells, Elk-1 immunodetection was processed on sections corresponding to the external segment of the globus pallidus $(G P e)$ and the substantia nigra pars reticulata $(\mathrm{SNr})$ levels. Note in both cases the clear decrease $(*)$ of the neuropil immunoreactivity in the GPe $(B)$ and the $\mathrm{SNr}(D)$ ipsilateral to the lesion when compared with the contralateral side of the lesion ( $A, C$, respectively).

\section{Sham}
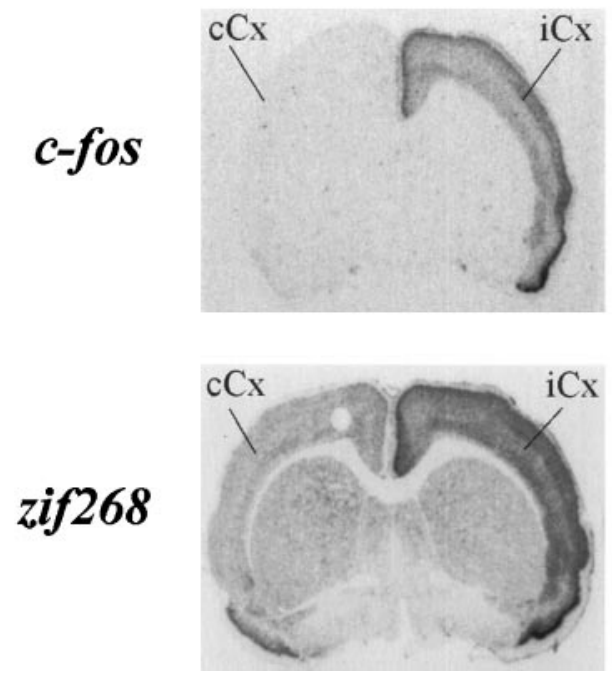

\section{Stim}
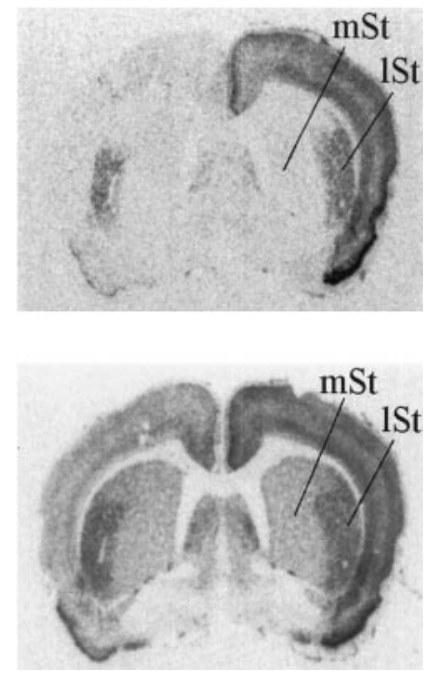

Figure 6. c-fos and zif268 mRNA induction after unilateral electrical stimulation of the corticostriatal pathway. Adjacent brain sections were in situ-hybridized with ${ }^{33} \mathrm{P}-c$-fos and ${ }^{33} \mathrm{P}-z i f 268$ antisense probes. Left panels, In sham-operated (Sham) rats, c-fos and zif $268 \mathrm{mRNAs}$ are induced in the cortex ipsilateral to the electrode implantation. In the entire striatum, whereas c-fos is not detectable, a constitutive expression of zif268 is observable. Right panels, In stimulated (Stim) rats, c-fos and zif268 mRNAs are slightly induced in the cortex ipsilateral to the stimulation. In the lateral part of the striatum, a restricted bilateral induction is strongly observed for both messengers, when compared with the medial area. $i C x$, Ipsilateral cortex; $c C x$, contralateral cortex to the electrode implantation; $m S t, l S t$, medial and lateral parts of the striatum, respectively.
Hipskind, unpublished observations). Nevertheless, the striatal extracts yielded a band of $62 \mathrm{kDa}$ that showed a slight increase in immunoreactivity in the lateral versus the medial area (Fig. 8, right panels). Once again, equal amounts of Elk-1 protein were detected in both striatal regions. Thus activation corresponds to a moderate increase in P-Elk-1.

\section{Hyperphosphorylated Elk-1 proteins are colocalized in striatal cells with a strong zif268 mRNA induction}

The striatal region in which phosphorylation of Elk-1 was increased corresponded to that showing IEG mRNA induction (compare Figs. 6, 7). To correlate this more directly, sections were processed for both phosphoimmunostaining and IEG mRNA in situ hybridization (Fig. 9). In the lateral striatum, all neurons with a strong P-Elk-1 immunoreactivity also showed an increase in zif268 mRNA expression (Fig. 9, large arrows). As in the medial striatum, cells weakly immunoreactive for P-Elk-1 expressed basal levels of zif268 mRNA (Fig. 9, thin arrows). This implicates Elk-1 as an intermediate in the transcriptional regulation of IEGs controlled by SREs on glutamatergic stimulation of neurons.

\section{DISCUSSION}

Three central findings emerge from this study. First, Elk-1 is an exclusively neuronal transcription factor. Second, this transcription factor is, in its nonactivated state, present in the soma, dendrites, and axon terminals of neurons. Third, Elk-1 is phosphorylated on in vivo glutamatergic stimulation, and this phosphorylation can occur in various subcellular compartments (e.g., dendrites, soma, and also the nucleus).

\section{Elk-1 mRNA expression in the CNS of the rat}

Evidence for Elk-1 mRNA expression in the brain was variable when we began this study. Although Rao et al. (1989) had found, 


\section{P-ERK}
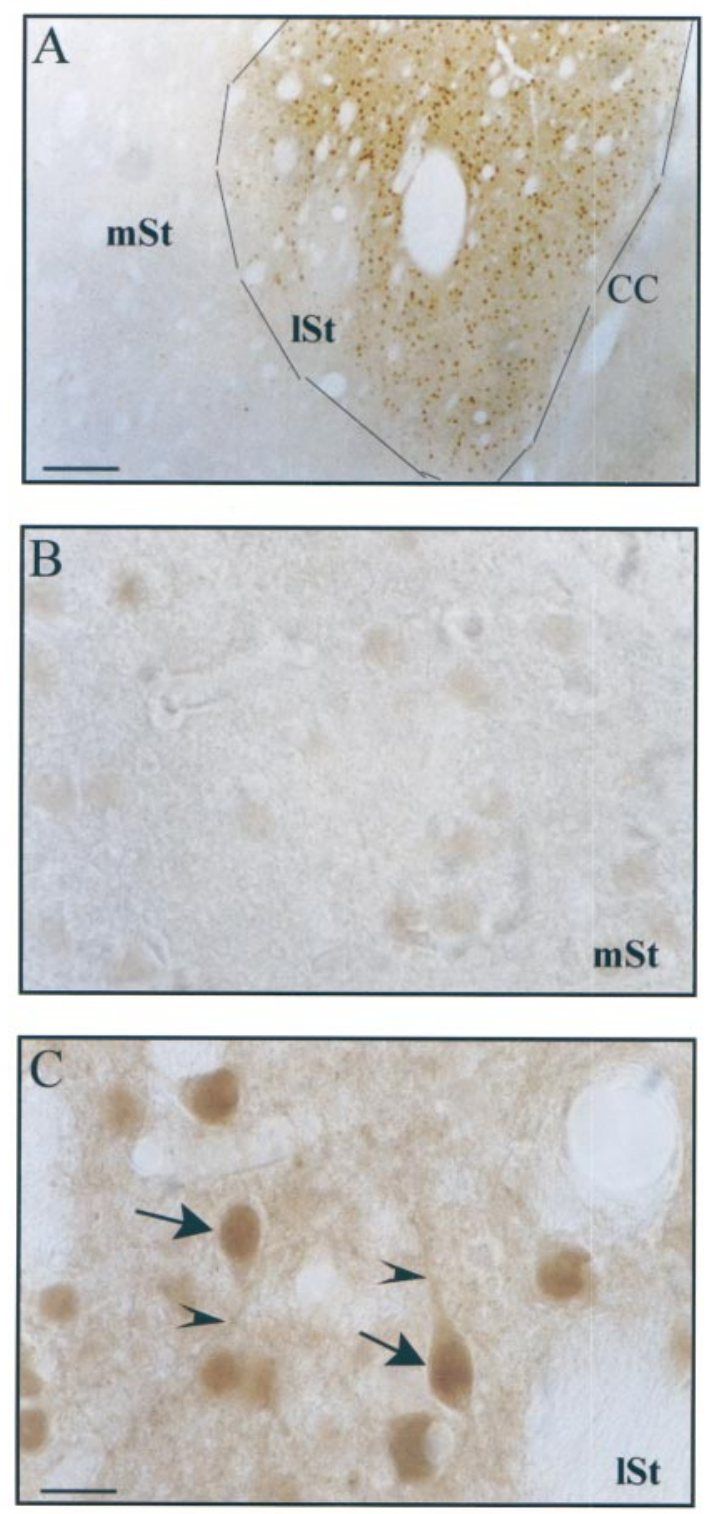

$\mathrm{D}$

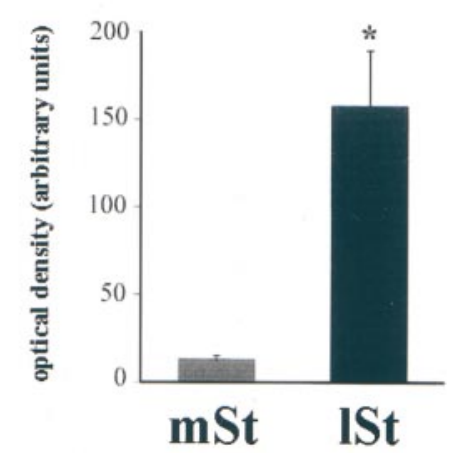

P-Elk-1
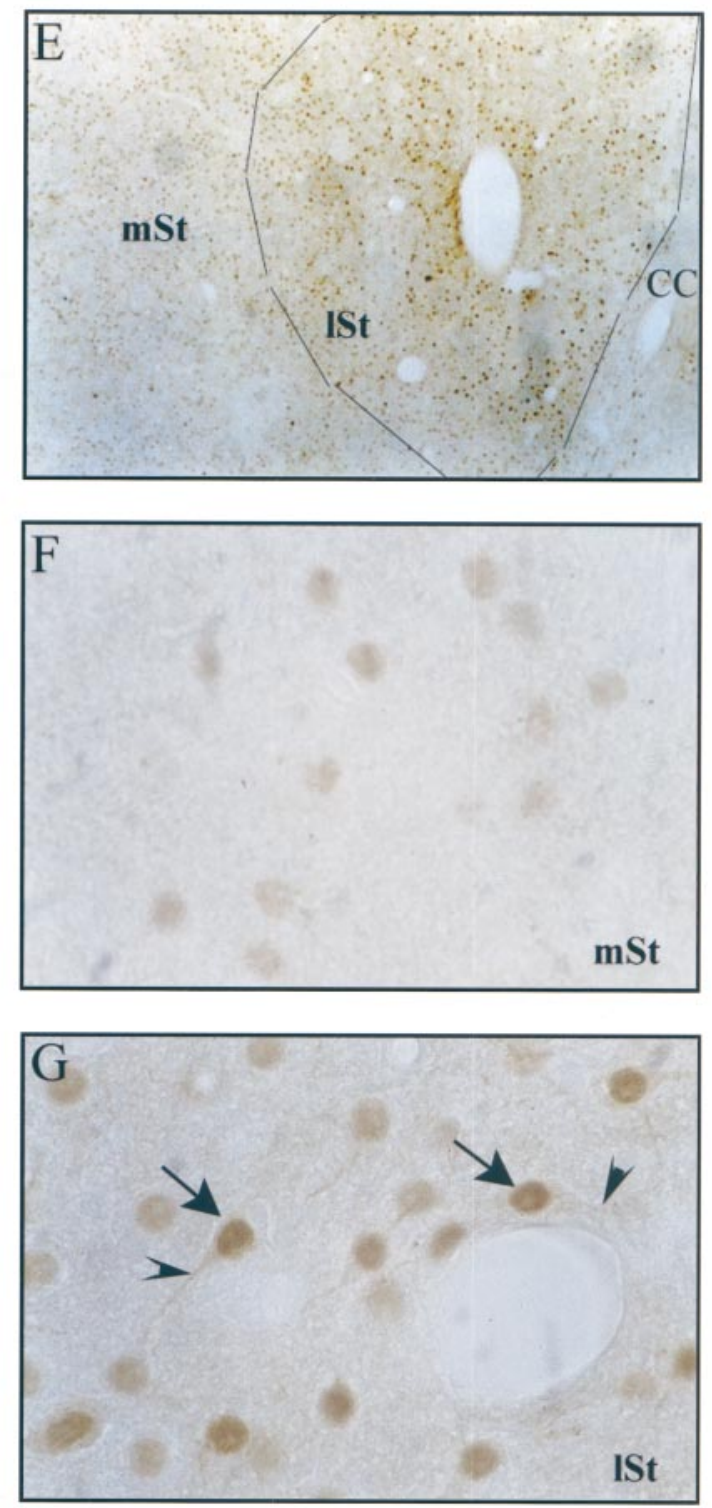

$\mathrm{H}$

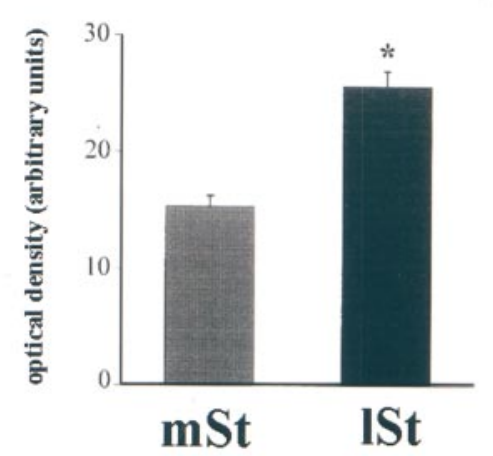

Figure 7. Phosphorylation of ERK and Elk-1 on corticostriatal activation. Adjacent striatal sections from stimulated rats $(n=3)$ were processed in parallel for immunocytochemistry using antibodies specific for phosphorylated forms of ERK $(P$-ERK $)$ and Elk-1 $(P$-Elk-1) proteins. Shown are ipsilateral striata to the stimulation site at low $(40 \times ; A, E)$ and high $(500 \times ; B, C, F, G)$ magnification. Note the increase of P-ERK $(A-C)$ and P-Elk-1 $(E-G)$ in the lateral part of the striatum. Arrows, Increase of nuclear immunolabeling. Arrowheads, Dendritic immunolabeled processes of striatal cells. $D, H$, Optical density measurements of P-ERK and P-Elk-1 immunoreactivities. Striatal sections were digitized with an image analyzer (IMSTAR), and precise delineation of medial and lateral parts was performed on each striatum (4 sections per rat; $n=3$ independent rats). Optical densities were measured and statistical comparisons were performed between lateral and medial parts of the striatum by a paired Student's $t$ test $\left({ }^{*} p<0.05 ; n=3\right.$ ). $m S t, l S t$, Medial and lateral parts of the striatum, respectively. Scale bar, $530 \mu \mathrm{m}$ for $16 \times ; 17 \mu \mathrm{m}$ for $500 \times$ magnification. 


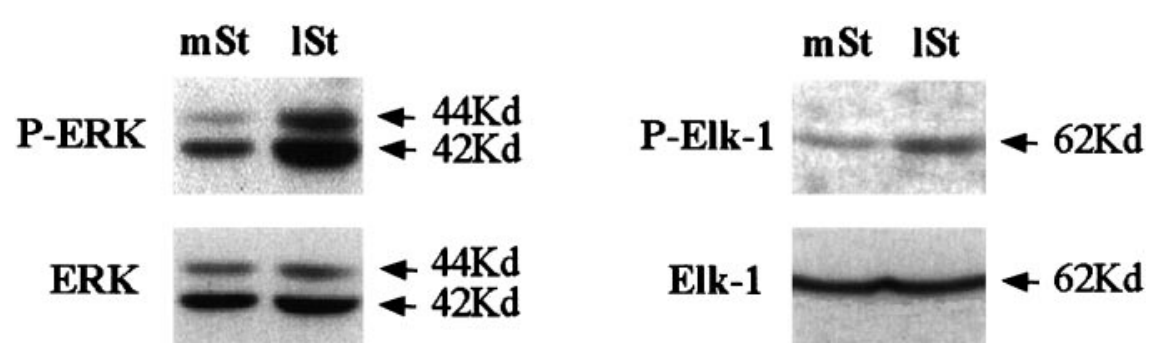

Figure 8. Western blot analysis of P-ERK and P-Elk-1 immunoreactivities. The medial and lateral parts of the striatum were rapidly dissected just after the end of the stimulation period, lysed, and processed for Western blot analysis. Left panels, P-ERK and ERK proteins were detected on the same blot after a stripping procedure. Note the marked increase of phosphorylated 42 and $44 \mathrm{kDa}$ proteins in the lateral striatal extracts relative to those from the medial striatum and the equal amount of ERK1 and ERK2 proteins in both extracts. Right panels, The same procedure was applied for P-Elk-1 and Elk-1 immunodetection. Note the slight increase of $62 \mathrm{kDa}$ phosphorylated protein in the lateral versus medial area with no variation of Elk-1 in these areas. The data presented are representative of three independent experiments, which gave similar results.
mSt

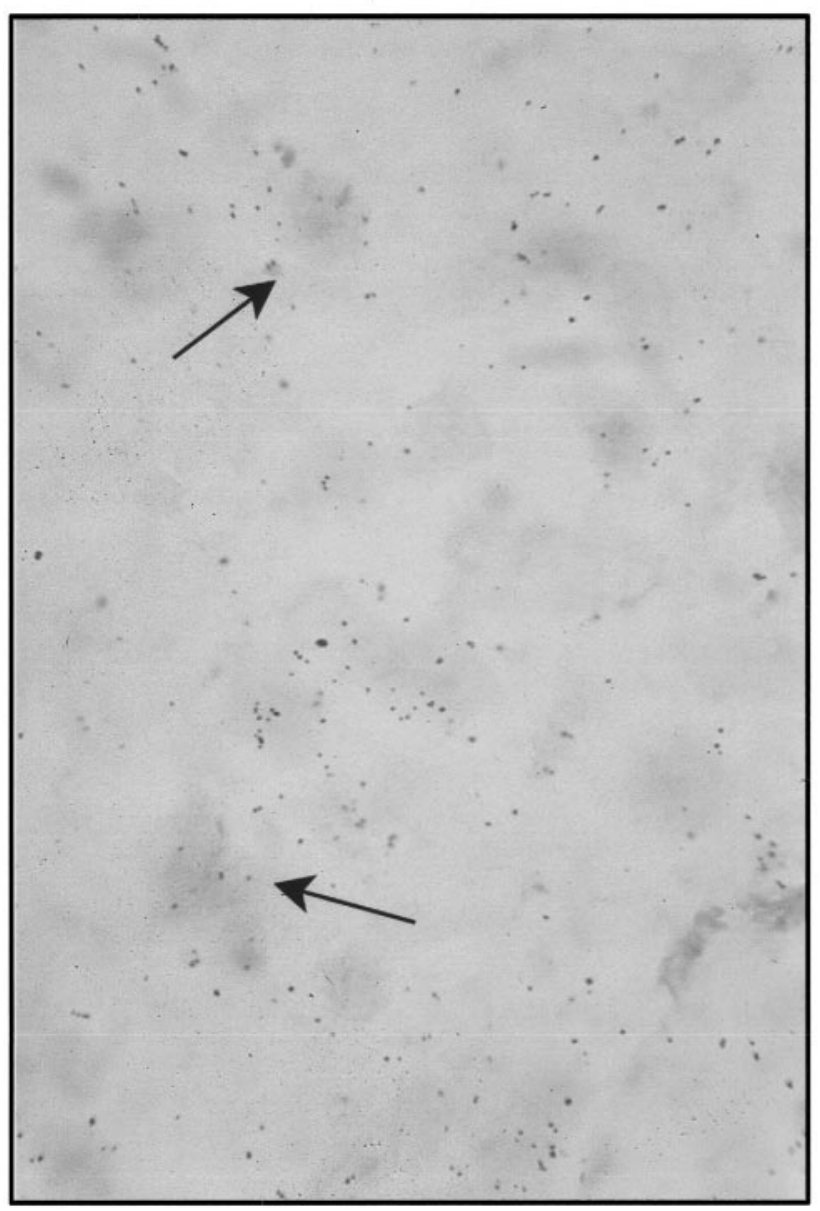

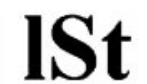

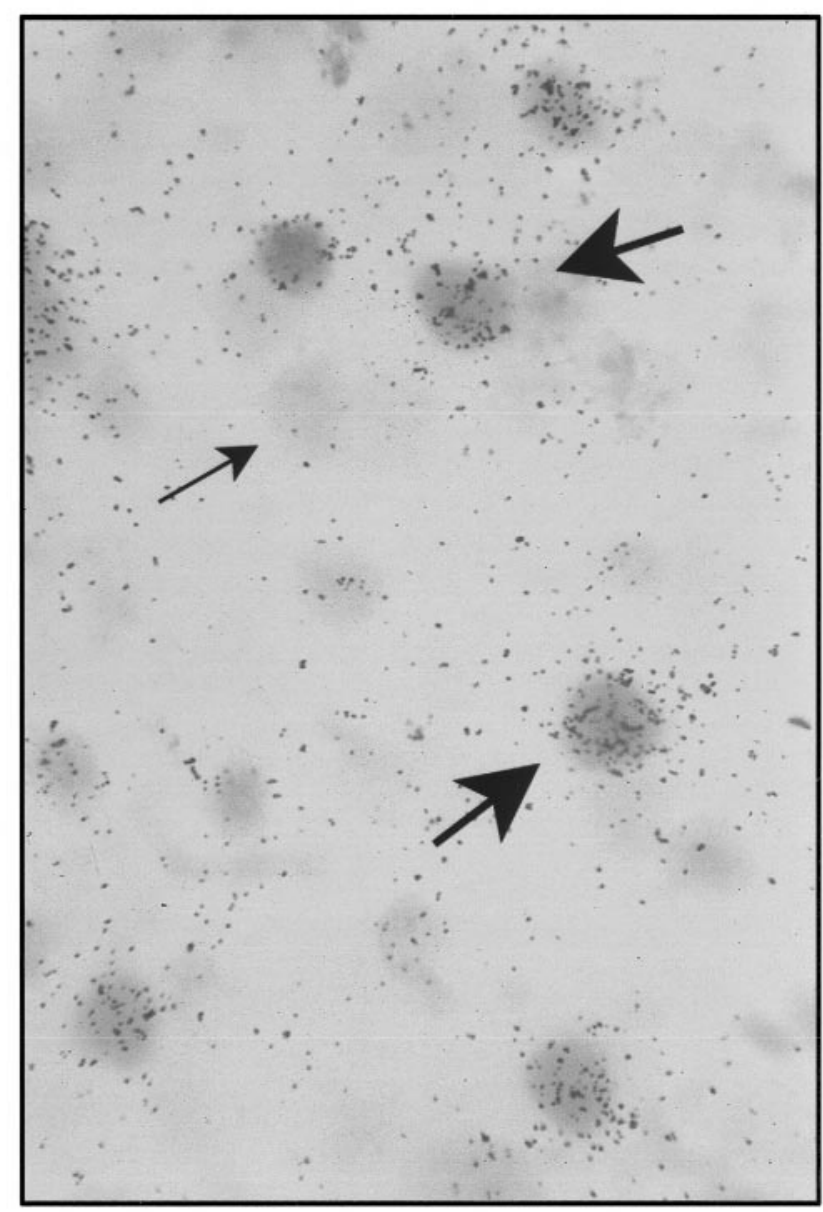

Figure 9. Double staining of P-Elk-1 immunoreactivity with zif268 mRNA in situ hybridization. Striatal sections from stimulated rats were coprocessed for P-Elk-1 with zif268 mRNA as described above. In both medial and lateral parts of the striatum, a constitutive expression of zif 268 mRNA is detectable, as well as a weak P-Elk-1 immunoreactivity (thin arrows). In the lateral part of the striatum, neurons presenting a strong P-Elk-1 immunoreactivity (large arrows) also show a marked increase in zif268 mRNA expression. Note the perfect correlation between strong P-Elk-1 immunoreactivity and zif268 mRNA expression.

by Northern blot analyses, barely significant levels of Elk-1 mRNA in the adult mouse brain, more recent data indicated a high level of Elk-1 mRNA expression in the brain in human, mouse, and rat (Giovane et al., 1994; Price et al., 1995) (Hipskind, unpublished observations). In situ hybridization using an antisense cRNA probe allowed us to identify regional differences in the expression of Elk-1 mRNAs in the rostrocaudal extension of the rat brain and to characterize neurons as the main cellular type expressing this transcription factor.

The regional variation in Elk-1 mRNA expression suggests that it may contribute to the regulation of neuronal function that varies in different parts of the brain. Elk-1 is one of the major 
substrates of the MAP kinase protein family. Among these kinases, ERK (Marais et al., 1993; Hipskind et al., 1994a,b), Jun $\mathrm{N}$-terminal kinase/stress-activated protein kinase (JNK/SAPK) (Cavigelli et al., 1995), and p38 MAPK (Raingeaud et al., 1996) have all been shown from in vivo and in vitro studies to phosphorylate Elk-1. ERK proteins are not only regulators of cell proliferation and differentiation but also likely regulators of hippocampal long-term potentiation (English and Sweatt, 1996; Martin et al., 1997). On the other hand, JNK/SAPK and $\mathrm{p} 38^{\mathrm{MAPK}}$ are activated by stress and UV irradiation (Cano et al., 1994; Dérijard et al., 1994; Pombo et al., 1994) and have been implicated in apoptosis in PC12 cells (Xia et al., 1995). The close correspondence between ERK2 mRNA (Thomas and Hunt, 1993) and Elk-1 mRNA expression is consistent with the hypothesis that Elk-1 is an in vivo substrate for ERK2. By contrast, some differences are found between JNK/SAPK mRNA (Carletti et al., 1995) and Elk-1 mRNA expression, as, for example, in the basal ganglia, in which JNK/SAPK mRNA levels are much lower than those of Elk-1. It would be interesting to determine whether other MAPKs, e.g., p38 $8^{\mathrm{MAPK}}$, are associated with stress-activated pathways in these regions.

Finally, our observation that Elk-1 is expressed principally in neuronal cell types is interesting, because IEGs, in particular c-fos, can be induced not only in neurons but also in astrocytes during the early postnatal stages and at adult age in response to severe injury (axotomy, hypoxia, and hypoglycemia) (for review, see Arenander and De Vellis, 1995). We have never found significant levels of Elk-1 mRNA or protein in astrocytes in vivo, whereas both are abundant in astrocytoma cell lines (Zinck et al., 1995). The constitutive expression of CREB in this cell type (Herdegen et al., 1993; Sato-Bigbee and Yu, 1993) implicates it as the transcription factor governing c-fos mRNA transcription. Because we have not measured SRF expression levels in astrocytes, the role of signals targeting this factor (Miranti et al., 1995) cannot be addressed. Nevertheless, this does not exclude a role for the TCF-SRF-SRE complexes in c-fos induction in glial cells at early stages of development and after injuries at adult age. In these instances, Elk-1 may be transiently induced in astrocytes, which may be reflected by its strong expression in astrocytoma cells. Alternatively, other TCFs and related proteins could be implicated in SRE-dependent c-fos induction in glial cells.

\section{Subcellular localization of Elk-1 protein in neurons}

When overexpressed by transient transfection of HeLa cells (Janknecht et al., 1994), recombinant Elk-1 was predominantly localized within the nucleus. ERKs, on their activation by growth factors, translocate to the nucleus (Chen et al., 1992), in which they can in turn phosphorylate Elk-1 in the C-terminal region (Marais et al., 1993). In sensory neurons of Aplysia, ERKs also translocate to the nucleus during 5-HT-induced long-term facilitation (Martin et al., 1997).

Using immunocytochemical detection of ERK proteins on brain sections, Fiore et al. (1993a) could localize the proteins in the soma surrounding the nucleus in neuronal cell bodies and in dendrites. Our immunocytochemical mapping of Elk-1 protein clearly indicates that, in addition to nuclear localization, Elk-1 protein is also present in the soma of cell bodies and dendrites and in some axon terminals. The significance of this pattern is demonstrated by two important controls for our immunocytochemical conditions. We found that CREB protein was exclusively nuclear, a result in agreement with the literature (Yamamoto et al., 1989), and that STAT3 was localized in the cytoplasm before stimulation (Darnell et al., 1994). Thus, in neuronal cells in vivo, Elk-1 may be a cytoplasmic substrate of ERK proteins, which are activated subsequent to excitatory synaptic inputs impinging on dendrites and neuronal soma.

The presence of Elk-1 in axon terminals of striatopallidal and striatonigral afferent terminals is very intriguing. In the $\mathrm{SNr}$, we have also localized ERKs in axon terminals (data not shown), as suggested already by Ortiz et al. (1995). Several lines of investigation have suggested that retrograde transport of ERKs could transduce signals from the nerve terminal to the nerve cell body (Johanson et al., 1995; Martin et al., 1997). Our observation that Elk-1 is also localized in nerve terminals suggests that it could also participate to the retrograde transport of signals.

\section{Hyperphosphorylation of Elk-1 on stimulation of corticostriatal afferents}

In cell culture models, the phosphorylation of Elk-1 plays a key role in the serum-induced transcriptional regulation of IEGs. Signaling pathways that lead to Elk-1 phosphorylation in culture cells are also activated on glutamate receptor stimulation in vitro (Bading and Greenberg, 1991) or in vivo (Fiore et al., 1993b; Kurino et al., 1995). Our work is the first attempt to demonstrate in vivo that Elk-1 can be hyperphosphorylated on glutamatergic electrical stimulation.

In our model of corticostriatal stimulation, ERKs were dramatically activated in the lateral part of the striatum, as determined by both immunocytochemical and biochemical criteria. Phosphorylated ERKs were present in nuclear, cytosolic, and dendritic compartments of neuronal cells. These data are interesting in light of the nuclear translocation of ERK in culture cells with serum activation (Chen et al., 1992) and with 5-HT activation, leading to long-term facilitation in Aplysia (Martin et al., 1997). The presence of activated ERK proteins in several different cellular compartments in vivo is consistent with its role in regulating diverse responses to extracellular signals (for review, see Seger and Krebs, 1995).

The cortical electrical stimulation also induced a significantly higher immunoreactivity with phospho-Elk-1 antibody in the projection field of stimulated striatal afferents. Hyperphosphorylation of Elk-1 was apparent in the nucleus, in which Elk-1 is likely to play a key role in the regulation of transcription, and to a lesser extent in other cellular compartments, i.e., in the cytosol in soma and dendrites. This observation is, to our knowledge, the first demonstration that Elk-1 is activated in a non-nuclear compartment. It further supports the notion that Elk-1 represents, in neuronal cells in vivo, a local target of activated ERKs and as such could relay the glutamatergic receptor signal from the membrane to the different intracellular compartments, including the nucleus.

The activation of NMDA receptors, which has been linked to SRE-dependent c-fos induction (Bading et al., 1993), is implicated in striatal Fos induction in our model of electrical cortical stimulation (Abo et al., 1994). Because cortical afferents specifically impinge on dendritic spines of striatal neurons (Smith and Bolam, 1990), and $\mathrm{Ca}^{2+}$ influx through NMDA receptors remains localized in the proximity of the receptor (Regehr et al., 1990), we suggest that the activation of ERKs and Elk-1 in dendrites could relay the signal triggered by this rise of dendritic calcium to the nucleus. This would be consistent with the recent demonstration that increased cytoplasmic calcium is linked to gene regulation by the SRE site, whereas increased nuclear calcium controls CREdriven gene expression (Hardingham et al., 1997).

Strong P-Elk-1 immunoreactivity always correlated with zif268 
mRNA induction. Nevertheless, we cannot exclude that other signaling pathways are also involved in IEG activation in our model. For example, $\mathrm{Ca}^{2+}$ entry could activate the SRE via targeting SRF itself (Xia et al., 1996) or CREs via calciumcalmodulin-dependent protein kinases (CamKs), as well as a PYK2-Ras-ERK pathway (Lev et al., 1995; Siciliano et al., 1996). CamKs can lead to CREB activation via its phosphorylation on $\mathrm{Ser}^{133}$, as can the ribosomal protein S6 kinase $\left(\mathrm{RSK}_{2}\right)$, a CREB kinase acting downstream of the ERK signaling cascade (Xing et al., 1996). Based on our results and those of Robertson et al. (1995), it seems likely that different combinations of these signaling systems are involved in IEG induction in the CNS.

Finally our data suggest that the ERK signaling cascade has an important role in regulating genes controlled by SREs via phosphorylation of Elk-1 in vivo. Genes driven by SREs in different promoter contexts, such as the IEG zif268, are likely to show differential sensitivity to this signaling pathway targeting Elk-1, which would support a crucial role of Elk-1 in synaptic plasticity.

\section{REFERENCES}

Abo V, Deniau JM, Rogard M, Besson MJ (1994) Involvement of the NMDA receptors in the induction of Fos expression in basal ganglia following electrical stimulation of the motor cortex. Eur J Neurosci [Suppl] 7:101.

Arenander A, De Vellis J (1995) Early-response gene expression in glial cells. In: Neuroglia (Kettenmann H, Ransom BR, eds), pp 510-522. New York: Oxford UP.

Bading H, Greenberg ME (1991) Stimulation of protein tyrosine phosphorylation by NMDA receptor activation. Science 253:912-914.

Bading H, Ginty DD, Greenberg ME (1993) Regulation of gene expression in hippocampal neurons by distinct signaling pathways. Science 260:181-186.

Cano E, Hazzalin CA, Mahadevan LC (1994) Anisomicyn-activated protein kinases $\mathrm{p} 45$ and $\mathrm{p} 55$ but not mitogen-activated protein kinases ERK-1 and -2 are implicated in the induction of c-fos and c-jun. Mol Cell Biol 14:7352-7362.

Carletti R, Tacconi S, Bettini E, Ferragutti F (1995) Stress activated protein kinases, a novel family of mitogen-activated protein kinases, are heterogeneously expressed in the adult rat brain and differentially distributed from extracellular-signal-regulated protein kinases. Neuroscience 69:1103-1110.

Cavigelli M, Dolfi F, Claret FX, Karin M (1995) Induction of c-fos expression through JNK-mediated TCF/ELK-1 phosphorylation. EMBO J 14:5957-5964.

Chen RH, Sarneki C, Blenis J (1992) Nuclear localization and regulation of erk- and rsk-encoded protein kinases. Mol Cell Biol 12:915-927.

Dalton S, Treisman R (1992) Characterization of of SAP-1, a protein recruited by serum response factor to the $c$-fos serum element. Cell 68:597-612.

Darnell JE, Kerr IM, Stark GR (1994) Jak-STAT pathways and transcriptional activation in response to IFNs and other extracellular signaling proteins. Science 264:1415-1421.

Dérijard B, Hibi M, Wu IH, Barrett T, Su B, Deng T, Karin M, Davis RJ (1994) JN K1: a protein kinase stimulated by UV light and Ha-Ras that binds and phosphorylates the c-jun activation domain. Cell 76:1025-1037.

English JD, Sweatt JD (1996) Activation of p42 mitogen-activated protein kinase in hippocampal long term potentiation. J Biol Chem 271:24329-24332.

Fiore RS, Bayer VE, Pelech SL, Posada J, Cooper JA, Baraban JM (1993a) p42 mitogen-activated protein kinase in brain: prominent localization in neuronal cell bodies and dendrites. Neuroscience 55:463-472.

Fiore RS, Murphy TH, Sanghera JS, Pelech SL, Baraban JM (1993b) Activation of mitogen-activated protein kinase by glutamate receptor stimulation in rat primary cortical cultures. J Neurochem 61:1626-1633.

Ghosh A, Greenberg ME (1995) Calcium signaling in neurons: molecular mechanisms and cellular consequences. Science 268:239-247.

Ginty DD (1997) Calcium regulation of gene expression: isn't spatial? Neuron 18:183-186.
Ginty DD, Bading H, Greenberg ME (1992) Trans-synaptic regulation of gene expression. Curr Opin Neurobiol 2:312-316.

Gille H, Sharrocks AD, Shaw PE (1992) Phosphorylation of transcription factor p62TCF by MAP kinase stimulates ternary complex formation at c-fos promoter. Nature 358:414-417.

Gille H, Kortenjann M, Thoma O, Moomaw C, Slaughter C, Cobb M, Shaw PE (1995) ERK phosphorylation potentiates Elk-1-mediated ternary complex formation and transactivation. EMBO J 14:951-962.

Giovane A, Pintzas A, Maira SM, Sobieszczuk P, Wasylyk B (1994) Net, a new ets transcription factor that is activated by ras. Genes Dev 8:1502-1513.

Hardingham GE, Chawla S, Johnson CM, Bading H (1997) Distinct functions of nuclear and cytoplasmic calcium in the control of gene expression. Nature 385:260-265.

Herdegen T, Sandkühler J, Gass P, Kiessling M, Bravo R, Zimmermann M (1993) Jun, Fox, Krox, and CREB transcription factor proteins in the rat cortex: basal expression and induction by spreading depression and epileptic seizures. J Comp Neurol 333:271-288.

Hill CS, Marais R, John S, Wynne J, Dalton S, Treisman R (1993) Functional analysis of a growth factor-responsive transcription factor complex. Cell 73:395-406.

Hipskind RA, Rao VN, Mueller CGF, Reddy ESP, Nordheim A (1991) Ets-related protein Elk-1 is homologous to the $c$-fos regulatory factor p62TCF. Nature 354:531-534.

Hipskind RA, Baccarini M, Nordheim A (1994a) Transient activation of RAF-1, MEK, and ERK2 coincides kinetically with ternary complex factor phosphorylation and immediate-early gene promoter activity in vivo. Mol Cell Biol 14:6219-6231.

Hipskind RA, Büscher D, Nordheim A, Baccarini M (1994b) Ras/MAP kinase-dependent and-independent signaling pathways target distinct ternary complex factors. Genes Dev 8:1803-1816.

Janknecht R, Zinck R, Ernst WH, Nordheim A (1994) Functional dissection of the transcription factor Elk-1. Oncogene 9:1273-1278.

Johanson SO, Crouch MF, Henry IA (1995) Retrograde axonal transport of signal transduction proteins in rat sciatic nerve. Brain Res 690:55-63.

Kurino M, Fukunaga K, Ushio Y, Miyamoto E (1995) Activation of Mitogen-Activated Kinase in cultured rat hippocampal neurons by stimulation of glutamate receptors. J Neurochem 65:1282-1289.

Lev S, Moreno H, Martinez R, Canoll P, Peles E, Musacchio JM, Plowman GD, Rudy B, Schlessinger J (1995) Protein tyrosine kinase PYK2 involved in $\mathrm{Ca}^{2+}$-induced regulation of ion channel and MAP kinase functions. Nature 376:737-745.

Lopez M, Oettgen P, Akbarali Y, Dendorfer U, Liberman TA (1994) ERP, a new member of the ets transcription factor/oncoprotein family: cloning, characterization and differential expression during B-cell development. Mol Cell Biol 14:3292-3309.

Marais R, Wynne J, Treisman R (1993) The SRF accessory protein Elk-1 contains a growth factor-regulated transcriptional activation domain. Cell 73:381-393.

Martin KC, Michael D, Rose JC, Barad M, Casadio A, Zhu H, Kandel ER (1997) MAP Kinase translocates into the nucleus of the presynaptic cell and is required for long-term facilitation in Aplysia. Neuron 18:899-912.

Miranti CK, Ginty DD, Huang G, Chatila T, Greenberg ME (1995) Calcium activates serum response factor-dependent transcription by a ras- and Elk-1 independent mechanism that involves a $\mathrm{Ca}^{2+} /$ calmodulin-dependent kinase. Mol Cell Biol 15:3672-3684.

Norman C, Runswick M, Pollok R, Treisman R (1988) Isolation and properties of cDNA clones encoding SRF, a transcription factor that binds to the $c$-fos serum response element. Cell 55:989-1003.

Ortiz J, Harris HW, Guitart X, Terwilliger RZ, Haycock JW, Nestler EJ (1995) Extracellular signal-regulated protein kinases (ERKs) and ERK kinase (MEK) in brain: regional distribution and regulation by chronic morphine. J Neurosci 15:1285-1297.

Paxinos G, Watson C (1986) The rat brain in stereotaxic coordinates, Ed 2. New York: Academic.

Pingoud V, Zinck R, Hipskind RA, Janknecht R, Nordheim A (1994) Heterogeneity of ternary complex factors in HeLa cell nuclear extracts. J Biol Chem 269:23310-23317.

Pombo CM, Bonventre JV, Avruch J, Woodgett JR, Kiriakis JM, Force $\mathrm{T}$ (1994) The stress-activated protein kinases are major c-jun aminoterminal kinases activated by ischemia and reperfusion. J Biol Chem 269:26546-26551.

Price MA, Rogers AE, Treisman R (1995) Comparative analysis of 
ternary complex factors Elk-1, SAP-1a and SAP-2 (ERP/NET). EMBO J 14:2589-2601.

Raingeaud J, Whitmarsh AJ, Barrett T, Dérijard B, Davis RJ (1996) MKK3- and MKK6-regulated gene expression is mediated by the p38 mitogen-activated protein kinase signal transduction pathway. Mol Cell Biol 16:1247-1255.

Rao VN, Huebner K, Isobe M, Ar-Rushci A, Croce CM, Shyam E, Reddy P (1989) elk, tissue-specific ets-related genes on chromosomes $\mathrm{X}$ and near translocation breakpoints. Science 244:66-70.

Regehr WG, Tank DW (1990) Postsynaptic NMDA receptor-mediated calcium accumulation in hippocampal CA1 pyramidal cell dendrites. Nature 345:807-810.

Robertson LM, Kerpolla TK, Vendrell M, Luk D, Smeyne RJ, Bocchiara C, Morgan JI, Curran T (1995) Regulation of c-fos expression in transgenic mice requires multiple interdependent transcription control elements. Neuron 14:214-252.

Sato-Bigbee C, Yu RK (1993) Presence of a cyclic AMP response element-binding protein in oligodendrocytes. J Neurochem 6:2106-2110.

Schröter H, Mueller CGF, Meese K, Nordheim A (1990) Synergism in ternary complex formation between the dimeric glycoprotein $\mathrm{p} 67^{\mathrm{SRF}}$, polypeptide $\mathrm{p} 62^{\mathrm{TCF}}$ and the c-fos serum response element. EMBO J 9:1123-1130.

Seger R, Krebs EG (1995) The MAPK signaling pathway. FASEB J 9:726-735.

Sgambato V, Abo V, Rogard M, Besson MJ, Deniau JM (1997) Effect of electrical stimulation of the cerebral cortex on the expression of the Fos protein in the basal ganglia. Neuroscience 81:93-112.

Shaw PE, Schröter H, Nordheim A (1989) The ability of a ternary complex to form over the serum response element correlates with serum inducibility of the human c-fos promoter. Cell 56:563-572.

Sheng M, Greenberg ME (1990) The regulation and function of $c$-fos and other immediate early genes in the nervous system. Neuron 4:477-485.

Siciliano JC, Toutant M, Derkinderen P, Sasaki T, Girault JA (1996) Differential regulation of proline-rich tyrosine kinase $2 /$ cell adhesion kinase $\beta$ (PYK2/CAK $\beta$ ) and pp125FAK by glutamate and depolarization in rat hippocampus. J Biol Chem 271:28942-28946.

Smith AD, Bolam JP (1990) The neural network of the basal ganglia as revealed by the study of synaptic connections of identified neurons. Trends Neurosci 13:259-265.

Thomas KL, Hunt SP (1993) The regional distribution of extracellularly regulated kinase- 1 and -2 messenger RNA in the adult rat central nervous system. Neuroscience 56:741-757.

Treisman R (1986) Identification of a protein-binding site that mediates the transcriptional response of the $c$-fos gene to serum factors. Cell 46:657-574.

Treisman R (1992) The serum response element. Trends Biochem Sci 17:423-426.

Treisman R (1995) Journey to the surface of the cell: Fos regulation and the SRE. EMBO J 14:4905-4913.

Wasylyk B, Hahn SL, Giovane A (1993) The Ets family of transcription factors. Eur J Biochem 211:7-18.

Xia Z, Dickens M, Raingeaud J, Davis RJ, Greenberg ME (1995) Opposing effects of ERK and JNK-p38 MAPK on apoptosis. Science 270:1326-1331.

Xia Z, Dudek H, Miranti CK, Greenberg ME (1996) Calcium influx via the NMDA receptor induces immediate early gene transcription by a MAP kinase/ERK-dependent mechanism. J Neurosci 17:5425-5436.

Xing J, Ginty DD, Greenberg ME (1996) Coupling of the ras-MAPK pathway to gene activation by RSK2, a growth-factor-regulated CREB kinase. Science 273:959-963.

Yamamoto KK, Gonzales GA, Biggs WH, Montminy ME (1989) Phosphorylation-induced binding and transcriptional efficacy of nuclear factor CREB. Nature 334:494-498.

Zinck R, Hipskind RA, Pingoud V, Nordheim A (1993) c-fos transcriptional activation and repression correlate temporally with the phosphorylation status of TCF. EMBO J 12:2377-2387.

Zinck R, Cahill MA, Kracht M, Sachsenmaier C, Hipskind RA, Nordheim A (1995) Protein synthesis inhibitors reveal differential regulation of mitogen-activated protein kinase and stress-activated protein kinase pathways that converge on Elk-1. Mol Cell Biol 15:4930-4938. 